\author{
ANNA HEDO, \\ Borys Grinchenko Kyiv University (Kyiv, Ukraine) \\ e-mail: a.hedo@kubg.edu.ua,ORCID 0000-0003-4151-0747 \\ OLGA SARAJEVA, \\ Priazovskyi State Technical University (Mariupol, Ukraine) \\ e-mail: saraeva.ov84@gmail.com,ORCID 0000-0001-5305-6751
}

\title{
GREEKS IN ODESSA (END OF THE 18TH - BEGINNING OF THE 20th CENTURY): HISTORIOGRAPHICAL DIMENSION
}

\begin{abstract}
The article has studied and systematized a set of major scientific papers on the ethnic history of the Greeks in Odessa, has identified and argued the stages of development of the historiographical tradition of the problem, has conducted the comparative analysis of directions and priorities of research on the Greeks in Odessa and has traced their evolution in accordance with changes in socio-political context. Historiographical work on the problem has been classified by chronological criteria. It is noted that during the imperial era, research did not go beyond clarifying certain issues of resettlement in the context of the colonization policy of the Russian government. In the research of Soviet historians in the general history of colonization by the Greeks of Odessa, military colonization stands out. At the same time, the socio-economic aspects of the functioning of the Greek community deserved special attention of Soviet historiography. The expansion of the range of research, inclusion of issues of commercial and social activities of Greeks occurs at the present stage of studying the problem and is connected with the intensification of Greek studies in Ukraine. It is proved that the lack of legal autonomy of the Odessa Greek community, the mobility of its representatives did not contribute to the scientific awareness of the Greeks in Odessa (unlike in Nizhyn and Azov) as a separate community with a whole set of distinctive features. Therefore, their history was considered within the context of the history of the foundation and development of the city. Despite the recent appearance of interesting articles on charitable, trade, commercial, cultural and educational activities of the Greek community of Odessa, it is still waiting for an ordered and comprehensive study.
\end{abstract}

Key word: historiography of the problem; historiographical situation; Greeks in Odessa.

\section{Introduction}

Among the areas of contemporary Ukrainian historiography, Greek studies occupy a special place. During the years of independence, they were formed into a powerful, dynamic and in some way institutionalized branch of domestic historical science. The considerable influence of the Greek diaspora on the economic and cultural life of some Ukrainian territories, the level and fruitfulness of relations with the environment, the phenomenon of legally formalized and socially organized Greek communities determine the constant research interest in the problems of their historical development. On the other hand, domestic historiography in a certain way compensates for the lack of attention to Greek issues that existed in Soviet times, when the ethnic aspect of the historical process was disregarded, and the problems of national minorities (and not only Greek) were hardly considered.

Instead, today the results of studying the problem are both generalizing works on the history of Greeks in Ukraine in general or the history of individual Greek centers in particular, and works that cover certain aspects of Greek communities - cultural, educational, economic, charitable and more. Taking into account the groundwork of predecessors, we can talk about a large and diversified scientific achievements that require historiographical systematization and analysis. The controversy that is taking place today on a number of issues - the reasons and nature of the formation of Greek centers, their political and legal status, features of economic and cultural life further actualizes the historiographical dimension of the problem.

The purpose of this study is to determine the degree of the study of the Greeks' history in Odessa on the basis of a comprehensive historiographical analysis of the works of researchers of the 19th - early 21 st centuries.

Some historiographical aspects and attempts to systematize works on the history of the Greeks of Odessa were reflected in the works by $\mathrm{O}$. Yas and V. Volonyts. $O$. Yas identified three stages in the study of the problem: the first (first half of the 19th century) was characterized by the emergence only of chronological essays; the second (second half of the 19th century) expanded the range of research in the best traditions of official Russian historiography, and the third stage is Soviet historiography, which studied mostly the activities of patriotic societies (Yas, 1994). According to V. Volonyts, the historiography of the imperial and Soviet eras did not go beyond clarifying certain issues of resettlement in the context of the colonization policy of the Russian government, paying attention to military colonization. The expansion of the range of research, inclusion of issues of commercial and social activities of Greeks occurs at the present stage of 
studying the problem and is connected with the intensification of Greek studies in Ukraine (Volonyts, 2005; 2011a).

\section{Research methods}

To achieve this purpose, we have used comparativehistorical method (to compare the views of scholars, different sources), problem-chronological method (to distinguish certain problems that were raised in historiography at different stages of its development), historical-genetic method (to determine the conditionality of the Greek community of Odessa, the influence of historical memory on the processes of ethnocultural revival), historicaltypological method (to define typical features of historiography of a particular period), the method of historiographical synthesis. The combination of different methods allowed to better understand the features of the views of different authors and compare their views on the problem.

\section{Results and Discussion}

The primacy in covering the place and role of the Greeks in the history of Odessa belongs to A. Skalkowski. The researcher noted that "a city was founded in Khadjibey, now it is so flourishing Odessa" (Skalkowski, 1850-53: 272) for the Greek settlers. It is difficult to agree with this opinion, although the assessment of the Greek influence on the formation of Odessa presented by A. Skalkowski is of certain interest. Interestingly, the author believed that these Greeks did not play an important role either in terms of military service or in terms of numbers (Skalkowski, 1850-53: 272).

At the same time, A. Skalkowski explained the resettlement of Greeks around Odessa by the desire to reward those who fought on the side of Russia against Turkey with lands in southern Ukraine, as well as to attract the Christian population of the North-Eastern Mediterranean. In particular, the researcher wrote: "The essence of this proposal (by de Ribas - author's note) consisted of two parts: 1) to settle Greeks and Albanians who arrived in Russia, served in the Russian army, who remained in the Novorossiysk region after the campaign almost without shelter, on the outskirts of Odessa, giving them plots of land for settlement. Up to 15,000 acres of land were allocated for this and the necessary sums were allocated to acquire their first farm. They formed a division called the Greek in 300 private soldiers with the required number of officers. There were up to 200 of them in Odessa and they expected much more. 2) For the multiplication of inhabitants in Odessa, peoples of the same faith were called from the Archipelago for their settlement in the city" (Skalkowski, 1836: 43-44).

The researcher noted that the Greeks received significant sums of money, houses built at public expense and certain privileges, including tax exemptions. A. Skalkowski cited the results of this policy: in 1795, a division was already established, at the same time there was a resettlement of about 100 Greek families from the Archipelago, among whom were 27 merchants with their capital (Skalkowski, 1836: 46). In 1797, there were about 1,000 Greeks and Albanians in Odessa, although A. Skalkowski himself tends to consider the latter also of Greek origin. At the same time, the researcher believed that "hopes for greater emigration of the peoples sharing the same religion did not come true" (Skalkowski, 1836: 283).

A. Skalkowski did not make a clear division between military and non-military colonization of the city. He covered the organization of the Greek military division and the structure that regulated and supervised the resettlement process, namely the commission for the settlement of Greeks and Albanians. The historian noted that at the request of Greeks who did not speak Russian very well and were not familiar with local law, a 14-member Greek magistrate was established to replace the commission for the settlement of Greeks and Albanians.

In accordance with the ideological and methodological principles of the presentation of the material, which consisted in determining the leading role of individual officials appointed by the "wise monarch", the author focused on issues related to the activities of officials. Thus, the detailed coverage of the mission to St. Petersburg (1797) by the guardian of the Greek settlers, Colonel Kes-Oglu, who demanded a protection document and the status of porto franco for Odessa, attracts attention.

A. Skalkowski cited the number of subjects of the Greek crown who lived in the Novorossiysk region - 900 people (Skalkowski, 1848: 354) (but these were only temporary residents of the region, who came to the Russian Empire in trade or other affairs).

Information about the Greeks was given by K. Smolyaninov in his "History of Odessa" (Smolyaninov, 1853). He touched upon the process of resettlement of Greeks without analyzing Russia's policy towards Greek immigrants. However, the work considers government orders for the settlement of Greeks and Albanians, who came from the Archipelago and other foreign places, near Odessa, and mentions the establishment of a 3-company division. The statistical description of Odessa, well processed by K. Smolyaninov, was compiled by LieutenantGeneral N.M. Berdyaev on behalf of Paul I. The author provided information about the benefits and privileges granted to displaced Greeks. In general, using a wide range of sources, K. Smolyaninov cited a lot of empirical information, but did not make a conceptual analysis of processes.

G. Pisarevsky was the first to distinguish non-military, "peaceful" Greek colonization of Odessa from the general colonization flow of the south of the empire. His views were analyzed in detail by E. Zagorovsky, who considered the resettlement to Novorossia.

Describing the migration of Greeks to Odessa, E. Zagorovsky noted the activities of Count P. Zubov. But comparing G. Potemkin's colonization policy and the measures taken by P. Zubov, he came to the conclusion that the latter did not have enough energy and talent to organize a large-scale resettlement (Zagorovsky, 1913).

In 1881, the work of S. Bernstein (1881), was published, who immediately noted that his essay was not a self-sufficient study, but it was based on the work of A. Skalkowski and K. Smolyaninov and should serve as factual material for future researchers.

Analyzing the initial settlement of Odessa, the author concludes that there were few representatives of the local population among the inhabitants and foreigners, primarily Greeks, predominated. Their arrival, according to S. Bernstein, was caused by the invitation of de Ribas, furthermore the Greeks came mainly from the Archipelago and Albania (Bernstein, 1881: 16). The creation of "a military corps, called a division, up to 300 private soldiers, with a decent number of officers and other ranks" by de Ribas was of great importance (Bernstein, 1881: 17). In fact, the author traces the history of Odessa through the competition of Russian-Slavic and foreign elements, while the strengthening of the latter is assessed negatively. In 
particular, the creation of a foreign magistrate instead of a Greek one is considered in a similar way. S. Bernstein wrote: "At the request of foreigners living in Odessa, a special magistrate was established with the Russian magistrate. This introduced duality into the urban structure of Odessa, a duality that could not but have a deplorable effect on the course of affairs in the city. Competition between Russian and foreign elements was not possible for the former. It is clear that there were disputes, complaints, intrigues, which had to slow down the work of the urban system" (Bernstein, 1881: 19).

Interestingly, a little later, S. Bernstein contradicts himself, speaking of the population of Odessa in 1795. Thus, according to the census conducted by the city police, out of 2349 people (excluding nobles and officials), there were 224 Greeks, and, for example, 240 were Jews, 566 people were runaway peasants who registered as burghers (Bernstein, 1881: 18).

Rich factual material is presented in the fundamental edition "Odessa 1794-1894" prepared for the centenary of the city. Extensive informative source base of the essay was presented by cases from the archives of the Odessa City Duma, Novorossiysk and Bessarabian GovernorGeneral and Odessa Mayor. The work is mostly devoted to the history of city self-government, but the author also mentions the existence of a Greek magistrate in Odessa. The notes to this work, which presents valuable data from the list of Odessa merchants of Count Orlov from 1789, indicating the guild, name and size of the declared capital, are of scientific interest (Odessa ..., 1895).

Interesting information on the history of the Greek community in Odessa, in particular, the sums donated by community members for the construction of temples, was provided by L. Rossolimo (1995). Their size indicates the extremely large economic role of the Greeks in the development of Odessa. In the best traditions of the presentation of the material of that time, the role of Empress Catherine II was noted, who facilitated the resettlement of 54 Greeks to Odessa, who, according to the authors, "walked freely and happily" (Rossolimo, comp., 1995: 6). It is interesting that the author tries not only to emphasize the awareness and preservation of their own national ethnic community in the new conditions, but also to consider the development of national education through this prism.

Thus, large-scale work was conducted by researchers of the 19th - early 20th centuries to collect, record historical sources and ethnographic information, which became the basis for further scientific research, which was to further address relevant issues on Greek themes.

Soviet historical science continued to consider the problems of the ethnic history of the national minorities of southern Ukraine in the context of the general colonization process, focusing on social problems.

In Soviet times, the work by T. Theocharid, which expressed the view that military settlements not only performed defensive functions, but also had to play a significant role in intensifying trade in the Northern Black Sea coastal, was a thorough publication on the history of the Greeks of Odessa. Thus, T. Theocharidi was not inclined to distinguish between military and merchant migration, which, by his own logic, complemented each other (Theocharidi, 1930).

The author names the Russo-Turkish war of 17871791 and the conclusion of the Treaty of Jassy, which defined the principles of migration, the immediate pre- conditions of Greek military colonization in the late 18th early 19 th century. At the same time, the researcher believes that by insisting on the terms of the Treaty of Jassy, the Russian government sought to resume the process of Greek settlement of southern Ukraine, primarily east of the Dniester and along the Black Sea coastal.

Analyzing the process of founding Greek settlements in the area of Odessa, T. Theocharidi notes the formation of the Greek division, as well as the resettlement of 100 Greek families from the Archipelago. However, unlike many researchers of the earlier period, the author considers this resettlement "brilliant" due to the fact that a Greek magistrate was created (Theocharidi, 1930: 11).

Based on the analysis of the quantitative and qualitative composition of the Greek division, the author argues that the division consisted not only of Greeks but also of other peoples of Southeastern Europe. In addition, he notes the problems with the formation of personnel, and also gives examples of escape from the division. T. Theocharidi also writes about the material abuses of the local administration against the Greek community, as well as attempts to hide it from the central government: "KesOglu died at that time (January 6, 1799). By September, the amount of the abuses committed by him, as well as a number of other abuses not related to the life of the division, becomes known" (Theocharidi, 1930: 19).

It is also interesting that $\mathrm{T}$. Theocharidi, unlike many other researchers, considers the decision of Paul I to liquidate the Greek division (1797) to be quite objective. He sees the reasons for this in the fact that among the personnel of the Greeks 6 who served in the Russian army during the war with Turkey in 1787-1801, were not more than $25 \%$; others either did not fight or were not Greeks (Theocharidi, 1930: 16).

At the same time, the researcher noted that the financial abuses of the Greek administration were one of the reasons why the Greeks left Odessa at the end of the 18 th century. Also among such reasons, T. Theocharidi mentions the crop failure of 1799 , which led to the commercial decline of the city, reducing the number of ships entering the port and the disbandment of the division.

$\mathrm{T}$. Theocharidi also reconsidered the role of Richelieu in the development of Greek colonization of the Northern Black Sea coastal. Thus, he writes that the mayor of Odessa did not facilitate their resettlement, as A. Skalkowski wrote, but, on the contrary, tried to limit the amount of land cultivated by the Greeks, giving preference to the Germans. To confirm this, the researcher cites a letter from Richelieu, written in July 1805: "As the area of Vukovic is still not inhabited and not cultivated, the excess land from the villages (Kalagleya, Mayak and Bilyayivka) and mountains (Ovidiopol) will not be deprived and the battalion withdrawal will not be assigned" (Theocharidi, 1930: 22). Moreover, according to T. Theocharid, Richelieu repeatedly emphasized that the Greeks were incapable of cultivating the land and living permanently in a certain territory: "... that all his persistent convictions were not able to inspire the Odessa Greeks for a substantial population and cultivation of the land ... because more than 2 years, only 22 houses or dugouts were built, and the very adjacency with the colonists is inhabited by quarrels and difficulties between the authorities" (Theocharidi, 1930: 22).

In fact, according to $T$. Theocharid, the Odessa battalion was saved from complete liquidation only by prepara- 
tion for the next Russo-Turkish war of 1806-1812, and, accordingly, by the need to form new volunteer units.

Among the reasons for the liquidation of the battalion T. Theocharides sees: 1) the inability of the Greeks to pay for their own uniforms; 2) the transfer of some people to the Balaklava Battalion; 3 ) inconsistency of many with the condition according to which only those Greeks who served in the navy during the time of Catherine, in particular, in the Archipelago, were recorded in this part.

Summarizing the consequences of Greek migration to southern Ukraine, T. Theocharidi notes that the Russian government saw the development of agriculture here as a basis for further strengthening the influence of the empire and therefore, not having a surplus population, was forced to attract foreigners. The historian saw another reason in the need to protect the southern borders of the Russian Empire, especially after the destruction of the Zaporozhian Sich. At the same time, the researcher directly writes that attempts to attract immigrants for the colonization of southern Ukrainian lands were unsuccessful. In fact, according to the author, until 1795 - the formation of the Odessa division, the migration process remained inefficient.

Much less quantitative work is conducted on historical Hellenistic explorations of this period. Moreover, the history of the Greek diaspora in Ukraine has hardly been studied. The development of the issues of modern and contemporary history of Greece, as well as the vast majority of issues in world history, was monopolized by academic institutions in Moscow. But even there, despite incomparably greater opportunities, only G. Arsh systematically studied the era of national liberation struggle of the Greeks and, in particular, aspects of its close connection to the Russian Empire, especially to Odessa, Crimea, other areas of southern Ukraine, where a Greek diaspora was at that time.

G. Arsh makes the process of resettlement of Greeks to the Russian Empire dependent on the policy of the Russian Empire: "In the struggle against Turkey, the tsarist government sought to use the forces of enslaved peoples of the Balkan eager to throw off the Turkish yoke" (Arsh, 1965). At the same time, the author was primarily interested in the resettlement of Greeks from the Balkan provinces of the Ottoman Porte, those who ensured the economic power of Turks and could help the development of the southern lands of the Russian Empire. G. Arsh puts the middle and lower strata of the population in the first place within the emigrants: "Greek emigration to Russia can be literally called a real people's movement. And although among the settlers from Greece there were bishops, people from the princely families of Fanar, and large Greek landowners, the bulk of them were merchants, peasants, klephts, armatoles" (Arsh, 1965: 37).

The author distinguishes several major waves of emigration, listing them in chronological order. Thus, the author associates the creation of Greek settlements in Balaklava after the Russo-Turkish War of 1768-1774 with the active participation of Greeks in hostilities as volunteers, as well as the desire of the Russian government to create a border quarantine service on the Black Sea coastal lands (Arsh, 1965: 37)

The author connects the new wave of Greek emigration with the Russo-Turkish war of 1787-1791 and the annexation of the territories between the Bug and the Dniester to the empire (Arsh, 1965: 38). The center of Greek emigration was moved to Odessa, where former
Greek and Albanian volunteers received about 15,000 acres of land. To confirm the important role of the Greeks in the development of Odessa, the author cites the fact that the city's coat of arms had an inscription in Greek (Arsh, 1965: 40).

According to the author, agriculture, trade and handicrafts played the main role among the occupations of the new settlers. It is interesting that $G$. Arsh considers the fact of the decline of the Nizhyn Greek colony dependent on the opening of new trade routes by Greek merchants of the Northern Black Sea coastal (Arsh, 1965: 40). The researcher also provides information that in Russia in the early 19 th century, there were already 800 Greek trading companies.

The monograph by K. Augitidis, Greek historian, continued the tradition of a thorough study of Greek patriotic societies, which was established in the Soviet historiography by $\mathrm{G}$. Arsh. The author analyzed Russia's pragmatic motives for encouraging resettlement and the ideological rhetoric that accompanied the process. The historian noted that it was the conditions of economic development that forced Russia to fight with Porto for access to the Black Sea, and this led to an intercession policy towards Christian Greeks. Interestingly, the main reason for granting privileges to the Greeks was not interest in the development of trade, but the creation of a lasting positive impression of the Russian government, which could be useful in Russia's Balkan policy (Augitidis, 1987). In support of this thesis, K. Augitidis noted: "At the same time, we must not forget that tsarism is a reactionary regime. In matters concerning Turkey, it pursued its own goals, seeking to secure Russia's lasting influence in the Balkans. The privileges granted to Greek immigrants and communities in Russia were intended to give the Greeks the impression that tsarism "sincerely cared" for their welfare. The tsarist government also hoped that Greek emigrants, who would later return to their homeland, would become the bearers of pro-Russian policy in the Balkans" (Augitidis, 1987: 7).

N. Terentieva paid attention to the Greeks of Odessa during the period of independence. It is important to note that the author managed to go beyond the traditional Soviet historiography emphasis on the revolutionary emigration of Greeks to Odessa and the colonization process. Considering these obviously important aspects among other things, N. Terentieva at the same time paid attention to other, no less significant components of the Greek factor in Odessa. She cited vivid biographies of influential Greek merchants, founders of major trading houses Rally, Rodokanaki, English, Marazli, who made a significant contribution to the formation of the "face" of the capitalist, cosmopolitan city. Based on a large number of sources, N. Terentieva demonstrates the leading role played by Greek trading houses in the traditional export of bread for the Northern Black Sea region (Terentieva, Tyshchenko, 2001).

The researcher's special attention was drawn to the fact that the Greeks participated in the management of the city. In this regard, the charitable and administrative activities of G. Maraslis, who from 1878 to 1895 was the mayor of Odessa, are characterized. During this time, G. Maraslis built about 40 public and educational institutions, enterprises, cultural institutions. The appearance of a tram, gas lighting, construction of a central post office in Odessa is also connected with him. Under G. Maraslis's rule, shelters, canteens, and hospitals were also opened 
for poor Odessans (Terentieva, 1999: 218). As a result of careful work on the collection of source material scattered in various funds and newspaper publications, a holistic picture of the life and work of this outstanding figure was presented for the first time.

Much attention is paid to the history of the Greek Commercial School in Odessa. She connects the establishment of this educational institution with the patronage traditions of Odessa entrepreneurs and their charitable associations. In this regard, the author raised a very important issue related to the charitable activities of Greek merchants, which would later become a separate topic for Hellenistic studies.

The result of I. Kalmakan's research work was his work, which covers the ethnic history of the Greeks in Odessa from the moment of resettlement to the present day. The author follows the traditional view of the reasons for the migration of Greeks to Odessa, seeing them in the mutual combination of the interests of the Greek population, which considered Russia its ally in the fight against Porto, and the Russian government, which tried to solve the "Eastern question". Therefore, since its founding, Odessa had become a place of mass settlement of Greeks, which led to the emergence of one of the largest and most influential Greek communities in the south of the Russian Empire. The author identifies the main stages of its history. The period of $1794-1830$ is characterized by the accumulation of significant funds, the emergence of large trading houses. The basis of the prosperity of the Odessa Greeks was commerce, and the degree of development of Russian trade depended on the freedom and security of navigation on Greek ships. The second stage 1830 - the end of the 19th century - is characterized by the return of Greeks to their historical homeland, which led to a reduction in the size of the Greek community by more than $10 \%$. But despite the decrease in the share of Greek capital in the economy of Odessa, its absolute number continued to increase, and the Greeks played a significant role in city life. Odessa gradually became one of the centers of national spiritual life, books and newspapers were published in Greek, and Greek cultural and educational institutions functioned here (Kalmakan, 1996).

K. Augitidis undertook the task of analyzing the publishing activity of the Greeks in Odessa. The author noted that the first Greek printing house in the Northern Black Sea region was established in 1787, during the hostilities between Russia and Turkey. Determining the purpose of its creation, the researcher pays special attention to the need for information support of the national liberation struggle of the Balkan Greeks. To confirm this, the researcher emphasizes the support of "Filiki Eteria", as well as the Minister of Foreign Affairs of Russia I. Kapodistrias, in the establishment of the printing house. Among the factors that contributed to the creation of the Greek printing house in Odessa, K. Augitidis mentions the presence of a large and patriotic Hellenic community in the city; wealth of Odessa Greeks; the geographical proximity of Odessa to Greece and the close connection of the Russian Greeks with the motherland (Augitidis, 2003).

The article by M. Dmytrienko (1994), became important in view of posing new questions of the complex research of the Greek diaspora in Odessa. It stated that in the 19th century, the history of Greek settlement was mainly considered, while their participation in the eco- nomic, social and cultural life of the city in the general historical context of the development of the South of Ukraine was covered briefly. M. Dmytrienko insisted on a deeper analysis of the Greek factor in the history of Odessa. After all, among this "unique community of Odessa", in the words of the author, the Greeks were notable for their organization, ability to adapt, viability.

The collective monograph "Greeks on Ukrainian Territories" presents a generalized view of the history of Ukrainian-Greek relations. The researchers were able to analyze and prove that the diversity of socio-cultural conditions in the settlements of Greek immigrants (RussianPolish-Crimean border, Nizhyn, Hetmanate, Pryazovia, Black Sea coastal cities of the Russian Empire), different forms of colonization, diverse social and professional composition of different waves of emigration, the presence of ethnic groups of different origin, the level and intensity of connection with the metropolis and world Hellenism, changes in the colonization policy of the Russian government during the 17th and 19th centuries - all this led to several adaptive models of Greek immigrants. One was the Nizhyn community with a mobile merchant's office, part of which resided and engaged in trade far beyond Nizhyn. The second model was the semi-closed rural communities of Mariupol, whose connection with the outside Greek world had been minimized. The third was the elite trade and financial organizations of Odessa's Greek merchant families, which consisted mostly of members of the Greek aristocracy with broad international connections (Dmytrienko, Lytvyn at all, 2000).

In modern Hellenistics, a significant segment of research is devoted to the study of the role of Greek merchants in Odessa. Among the works devoted to the study of the history of Greek trade in the city of Odessa, the monograph of P. Herlihi "Odessa. History of the city, 1794-1914" should be noted (Herlihi, 1999). The author presents the history of the Black Sea coastalal city in a general retrospective perspective. Particular attention is paid to highlighting the role of Greek merchants in the development of foreign trade in Odessa. The researcher notes that D. Rally, G. Maraslis, F. Rodokanaki, K. Papudov and other Greek merchants played a leading role in the early development of Odessa's international trade. However, in the second half of the 19th century, the participation of Greeks in Odessa trade declined sharply. After the decline in grain exports through the port of Odessa, according to the author, many Greek merchants left Odessa.

The life of famous Greek merchants, including in Odessa, is described in the scientific collection "Ascetics and Patrons. Greek entrepreneurs and public figures in Ukraine in the 17th-20th centuries", which was the first attempt to determine the importance of the personal factor in social processes in the Greek environment and regions of compact residence of Greeks. The collection began the tradition of covering the professional activities of Greek merchants in the direction of biographical research (Podvyzhnyky i metsenaty..., 2001).

The history of "Filiki Eteria", its organizational structure and activities, along with historical portraits of the main figures of the organization occupy a central place in N. Terentieva's monograph "Greek secret society 'Filiki Eteria"'. Continuing the thesis about the significant role of merchants in the organization of the revolution, $\mathrm{N}$. Terentieva turned to the Greek environment of Odessa. According to her, the wealth and number of Odessa mer- 
chants of Greek origin, their patriotism, the favorable position of the Russian authorities on national initiatives were undoubtedly important factors that determined the role of Odessa as the cradle of the Greek revolution and homeland of "Filiki Eteria".

The researcher traced how a small secret group of unknown Odessa merchants turned into a strong and branched organization with large finances, broad support and geography, step by step. The analysis of the social composition of the company, a careful calculation of voluntary monetary contributions by Greek entrepreneurs deserved attention (Terentieva, 2005).

A book written by $\mathrm{N}$. Terentieva in co-authorship with O. Slyusarenko (2005). became a certain generalization of the economic plot of the history of the Greek diaspora. Entrepreneurial activity of the Greeks has long been in the field of view of N. Terentieva, the commercial factor of Greek life was widely depicted in her generalizing works on the ethnic history of the Greeks of Ukraine. The researcher published a number of articles on the history of Greek entrepreneurship in Odessa (Terentieva, 2001).

Researching the trade and economic activities of Greek merchants in the Ukrainian lands in the second half of the 17th-19th centuries, V.S. Volonyts pays attention to the Greek merchants in Odessa. She emphasizes that given the great trade opportunities that had been opened since the accession of Novorossia, in the early 19th century, representative offices of large Greek trading companies focused on grain exports appeared in Odessa. The Greeks had special national family traditions of trade, which accelerated the penetration of Russian exports in European markets. In the 19th century, the process of legislative regulation of trade activities of the Greeks of Odessa took place by granting the rights and privileges that regulated the mechanisms of obtaining citizenship, the functioning of foreign trade of Russian-subject Greeks and Greek-foreigners. According to the researcher, realizing the role of Greek merchants in the economy of Novorossiya, since the 1850 s, the government had expanded the possibilities of obtaining guilds and privileges for Greeks, which gradually unified and equalized Russian-subject Greeks and Greek-foreigners in legal terms (Volonyts, 2007)

In her research, V.S. Volonyts notes that representatives of wealthy Greek trading families, who had significant capital, became the founders of branches of trading houses in Odessa in order to expand the scope of the enterprise and develop new markets. Firms were institutions of family business. However, the growth of economic opportunities, the intensification of trade necessitated the separation of the branch from the central office and its functioning as independent trading company. Accumulating financial resources through the profitable operation of trading houses, the Greeks showed themselves in industrial and commercial activities. Merchants invested in profitable and cost-efficient sectors of the economy, light and food industries, but did not ignore the metallurgical companies and railway construction. Some businessmen managed to create profitable companies in the financial and credit business. Representatives of the Greek merchants played a significant role in the creation of equity mutual companies, by acquiring shares (units), or in positions in associated enterprises (Volonyts, 2011b).

\section{Conclusions}

The lack of legal autonomy of the Odessa Greek community, the mobility of its representatives, their inclusion in the general cosmopolitan urban society did not contribute to the scientific understanding of the Greeks of Odessa (unlike Nizhyn and Azov) as a separate community with a set of distinctive features. Therefore, their history was considered within the context of the history of the foundation and development of the city. Unfortunately, the traditions of superficial and selective coverage of their history have survived to this day. Despite the recent appearance of interesting articles on charitable, trade, commercial, cultural and educational activities of the Greek community of Odessa, it is still waiting for an ordered and comprehensive study.

Areas of further scientific research are determined by the need to:

- study of the world of everyday life of the Greeks in Odessa;

- application of the anthropological approach in the coverage of the Greek factor in Odessa and going beyond the narrow boundaries of descriptive biographies in the depiction of personality in historical development.

\section{REFERENCES}

Arsh, G.L. (1965). Tajnoe obshchestvo «Filiki Eteriya». Iz istorii bor'by Grecii za sverzhenie osmanskogo iga. Moscow: Nauka. 130 p. (in Russian)

Augitidis, K. (1987). Progressivnaya grecheskaya emigraciya $v$ Odesse (pervaya tret XIX V.). Kyiv: Vyshcha shkola. 41 p. (in Russian)

Augitidis, K.G. (2003). Izdatelskaya deyatelnost grekov Odessy (1829 - 1917). Odessa : «Astroprint». 128 p. (in Russian)

Bernstein, S. (1881). Istoricheskij i torgovo-ekonomicheskij ocherk Odessy v svyazi s Novorossijskim kraem. Odessa: Tipografiya L.Nitche. 233 p. (in Russian)

Dmytrienko, M. \& Lytvyn, V. \& Tomazov, V. \& Yakovlieva, L. \& Yas, O. (2000). Hreky na ukrainskykh terenakh. Kyiv: Lybid. 488 p. (in Ukrainian)

Dmytrienko, M.F. (1994). Hreky Odesy ta Odeshchyny: suchasne bachennia problemy. Odesi 200: Proceeding Papers. Odesa.124-125. (in Ukrainian)

Herlihi, P. (1999). Odesa. Istoriia mista, 1794-1914. Kyiv: Krytyka. 882 p. (in Ukrainian)

Kalmakan, I.K. (1996). Odesskaya grecheskaya obshchina: proshloe i nastoyashchee (1795-1996 gg.). Odessa; Afiny: Apollon. 160 p. (in Russian)

Odessa 1794-1894 gg. (1895). Odessa: Tip. A. SHul'ce, 1895. 942 c. (in Russian)

Podvyzhnyky $i$ metsenaty. Hretski pidpryiemtsi ta hromadski diiachi v Ukraini XVII-XX st. (2001): Zb. nauk. pr. K.: Instytut istorii Ukrainy NAN Ukrainy. 342. (in Ukrainian)

Rossolimo, L. (comp.) (1995). Grecheskaya cerkov sv. Troicy v Odesse. 1808-1908. 2-nd. Odessa: OKFA. 76 p. (in Russian)

Skalkowski, A. (1836). Hronologicheskoe obozrenie istoril Novorossijskogo kraya (1730-1823). CH.1: S 1730 do 1796 gg. Odessa. 43-44. (in Russian)

Skalkowski, A. (1848). Prostranstvo i narodonaselenie Novorossijskogo kraya. Novorossijskij kalendar' na 1849 god. Odessa. 412 p. (in Russian)

Skalkowski, A.A. (1850-1853). Opyt statisticheskogo opisaniya Novorossijskogo kraya. Odessa: Tip. Francova i Nitche, 1850-1853. CH.1-2. (in Russian)

Sliusarenko, O., Terentieva, N. (2005). Torhovo-ekonomichni zviazky narodiv Ukrainy i Hretsii: istorychni tradytsii ta sohodennia. K.: Vyd. dim «Kyievo-Mohylianska akademiia». 500 p. (in Ukrainian)

Smolyaninov, K. (1853). Istoriya Odessy. Odessa: Gor. tip. 284 p. (in Russian)

Terentieva, N. (2001) Odeski kuptsi Rodokanaki. Podvyzhnyky i metsenaty. Hretski pidpryiemtsi ta hromadski diiachi $v$ 
Ukraini. XVII-XIX st.: Zb. nauk. prats. K.: Instytut istorii Ukrainy NAN Ukrainy.153-166. (in Ukrainian)

Terentieva, N. (2005) Taiemne hretske tovarystvo «Filiki Eteriia». Kyiv: Instytut istorii Ukrainy NAN Ukrainy, 2005. 352 p. (in Ukrainian)

Terentieva, N.A. (1999). Greki v Ukraine: ekonomicheskaya $i$ kul'turno-prosvetitel'skaya deyatel'nost' XVII-XX vv. Kyiv: Akvilon-Press. 352 p. (in Russian)

Terentieva, N.O., Tyshchenko, H.V. (2001) Pidpryiemnytska diialnist hretskykh kuptsiv brativ Ralli. Podvyzhnyky y metsenaty. Hretski pidpryiemtsi ta hromadski diiachi $v$ Ukraini XVII - XX st. Kyiv: 133-140. (in Ukrainian)

Theocharidi, T. (1930) Hretska viiskova kolonizatsiia na Pivdni Ukrainy naprykintsi XVIII na pochatku XIX st. Odesa: Vydannia Odeskoi komisii kraieznavstva pry VUAN. 47 p. (in Ukrainian)

Volonyts, V. S. (2011a). Hretski torhovi domy v Odesi XIX stolittia. Visnyk Mariupolskoho derzhavnoho universytetu. Seriia: Istoriia. Politolohiia. (Vyp. 1.), 22-30. (in Ukrainian)
Volonyts, V.S. (2005). Do istoriohrafii vyvchennia hrekiv Odesy. Literatura ta kultura Polissia. Vyp. 28: Storinky istorii i kultury Polissia ta Ukrainy $v$ suchasnomu vysvitlenni. Nizhyn: Vydavnytstvo NDU im. M. Hoholia. 52-57. (in Ukrainian)

Volonyts, V.S. (2007). Torhovelno-komertsiina diialnist hrekivkuptsiv v Ukraini (seredyna XVII-XIX st.). (Master's thesis). Donetsk National University. 236 p. (in Ukrainian)

Volonyts, V.S. (2011b). Diyalnist hrekiv-kuptsiv na ukrainskykh terenakh u XVII-XIX st. u radianskii istoriohrafii. Skhid. 2011, № 4 (111). 84-86. (in Ukrainian)

Yas, A.V. (1994). Grecheskaya diaspora g. Odessy: istoriograficheskiy obzor issledovaniy. Odesi-200: Proceeding Paper. Odesa, 1994. S. 128-129. (in Russian)

Zagorovsky, E. (1913). Inostrannaya kolonizaciya Novorossii v XVIII veke. Odessa: Tipografiya S. Rozenshtrauha i N. Lemberga. 16 p. (in Russian)

\section{Анна Гедьо,}

Київський університет імені Бориса Грінченка (м. Київ, Україна)

e-mail: a.hedo@kubg.edu.ua,ORCID 0000-0003-4151-0747

Ольга Сараєва,

Приазовський державний технічний університет (м. Маріуполь, Україна)

e-mail: saraeva.ov84@gmail.com,ORCID 0000-0001-5305-6751

\section{ГРЕКИ ОДЕСИ (КІНЕЦЬ ХVIII - ПОЧАТОК ХХ СТ.): ІСТОРІОГРАФІЧНИЙ ВИМІР}

У статті вивчено і систематизовано комплекс основних наукових праць із питань етнічної історії греків Одеси, виділено та аргументовано етапи розвитку історіографічної традиції досліджуваної проблеми, здійснено порівняльний аналіз напрямків та пріоритетів дослідницького пошуку щодо греків Одеси та простежено їх еволюцію у відповідності до змін суспільно-політичного контексту. Історіографічний доробок із проблеми класифіковано за хронологічним критерієм. Зазначено, що за імперської доби дослідницькі пошуки не виходили за межі 3'ясування окремих питань переселення в контексті колонізаційної політики російського уряду. У дослідженнях радянських істориків в загальній історії колонізації Одеси греками виділяється військова колонізація. Водночас на особливу увагу радянської історіографії заслуговували соціально-економічні аспекти функціонування грецької громади. Розширення спектру досліджень, включення до нього питань комерційної, громадської діяльності греків припадає на сучасний етап вивчення проблеми й пов'язане 3 активізацією грецьких студій в Україні. Доведено, що відсутність юридичної автономії одеської грецької спільноти, мобільність її представників не сприяли усвідомленню науковим загалом греків Одеси (на відміну від ніжинських та приазовських) як виокремленої спільноти 3 цілим комплексом самобутніх рис. Тому їх історія розглядалася у контексті історії заснування та розвитку міста. Не зважаючи на появу останнім часом цікавих статей із доброчинної, торговельнокомерційної, культурно-освітньої діяльності грецької спільноти Одещини, вона ще чекає на впорядковане й цілісне дослідження.

Ключові слова: історіографія проблеми; історіографрічна ситуація; одеські греки.

(C) Anna Hedo, Olga Sarajeva

Надійшла до редакції: 01.09.2020

Прийнята до друку: 02.11.2020 